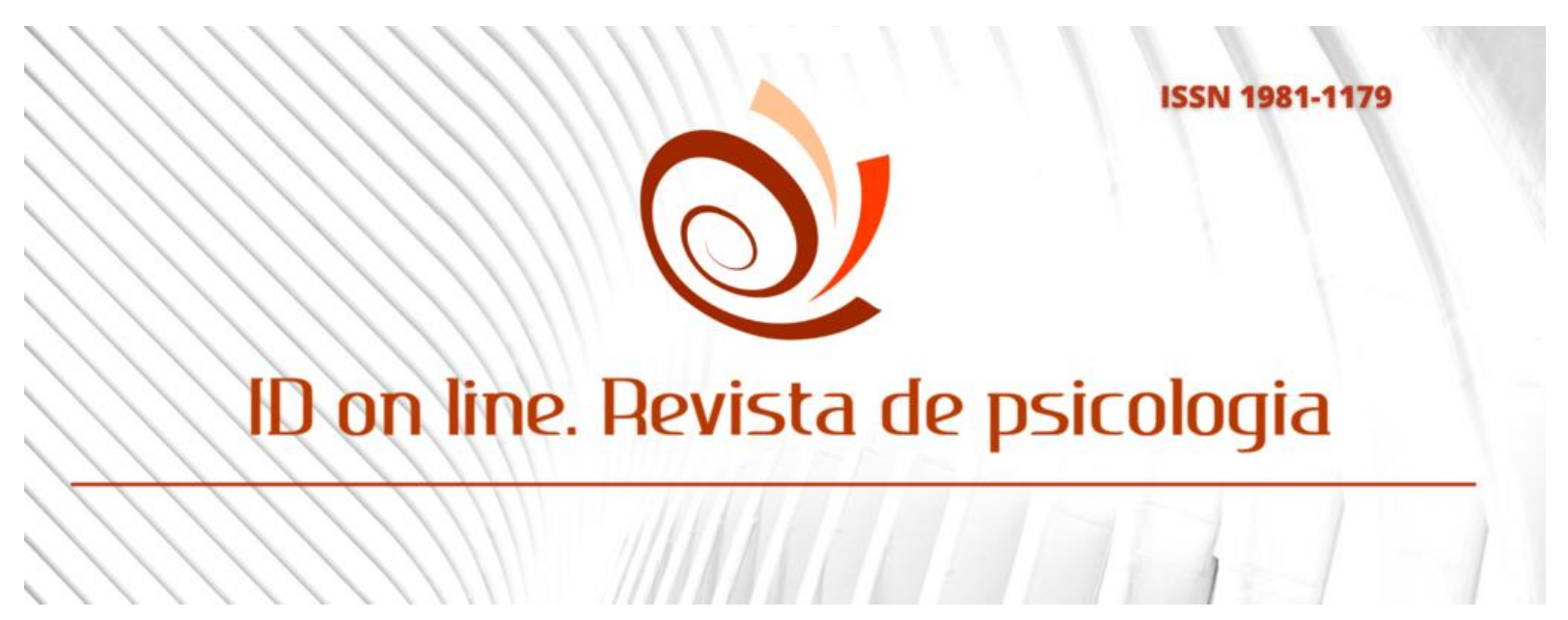

DOI: 10.14295/idonline.v16i59.3363

Artigo

\title{
Formação de Professoras/Professores e Pesquisadoras/Pesquisadores Indígenas na Região de Abrangência do Opará
}

\author{
Roberto Remígio Florêncio ${ }^{1}$, Pedro Rodolpho Jungers Abib ${ }^{2}$
}

\begin{abstract}
Resumo: O presente trabalho apresenta um conjunto de estudos, baseado em pesquisas de natureza empírica, bibliográfica e documental, acerca da formação de professores e pesquisadores indígenas na Região de Abrangência do Opará, no sertão sanfranciscano do estado de Pernambuco. Buscou-se conhecer e apresentar as possibilidades e resultados da formação, universitária e em nível de pós-graduação, dos professores e professoras indígenas das comunidades locais. Defendemos os pressupostos da Educação Intercultural e estudos decoloniais (QUIJANO, 2006; MIGNOLO, 2004) como prova da capacidade de participação efetiva dos sujeitos nas decisões sociopolíticas que envolvem os povos nativos brasileiros. Apresentamos narrativas indígenas e considerações sobre as pesquisas de estudantes indígenas matriculados em cursos de Graduação e PósGraduação oferecidos por instituições locais e pela Ação Saberes Indígenas na Escola. Os resultados, baseados na Análise do Discurso (MAINGUENEAU, 2010), dão conta de uma significativa leva de professores indígenas locais desenvolvendo pesquisas em programas de pós-graduação em diversos níveis. Como conclusões, percebemos as dificuldades dos pesquisadores indígenas na condução de suas pesquisas e, por isso, apontamos a necessidade de políticas públicas para a efetivação da pesquisa intercultural e para o pleno desenvolvimento da Educação Escolar Indígena, específica e diferenciada nas comunidades locais.
\end{abstract}

Palavras-chave: Interculturalidade. Educação Escolar Indígena. Pesquisa. Saberes Indígenas.

\section{Training of Indigenous Professors and Researchers in the Coverage Region of Opará}

\begin{abstract}
The present work presents a set of studies, based on empirical, bibliographical and documental research, about the formation of indigenous teachers and researchers in the Coverage Region of the Opará River, in the Sanfranciscan hinterland of the state of Pernambuco. We sought to know and present the possibilities and results of training, at university and at the postgraduate level, of indigenous teachers from local communities. We defend the assumptions of Intercultural Education and decolonial studies (QUIJANO, 2006; MIGNOLO, 2004) as proof of the subjects' capacity for effective participation in sociopolitical decisions involving Brazilian native peoples. We present indigenous narratives and considerations about the research of indigenous students enrolled in Undergraduate and Graduate courses offered by local institutions and by Ação Saberes Indígenas na Escola. The results, based on Discourse Analysis (MAINGUENEAU, 2010), show a significant wave of local

\footnotetext{
${ }^{1}$ Doutorando em Educação - UFBA; Professor Língua Portuguesa. Universidade Federal da Bahia - UFBA/ IF Sertão - PE. betoremigio@yahoo.com.br;

${ }^{2}$ Pós-doutorado pela Université Paris-Ouest Nanterre la Défense, PARIS OUEST, França. Doutor em Educação (UNICAMP) e Mestre em Educação (UFBA). pedroabib@gmail.com.
} 
indigenous professors carrying out research in graduate programs at different levels. As conclusions, we perceive the difficulties of indigenous researchers in conducting their research and, therefore, we point out the need for public policies to carry out intercultural research and for the full development of Indigenous School Education, specific and differentiated in local communities.

Keywords: Interculturality. Interculturality. Indigenous School Education. Search. Indigenous Knowledge.

\section{Introdução}

Desde o início da colonização portuguesa, por terem sido os primeiros a sofrerem os embates da invasão e, posteriormente, ao não serem reconhecidos como indígenas, por estarem já bastante "aculturados", no início do século XX, os povos nativos da região Nordeste do Brasil sofreram investidas de negação de suas existências, em avassaladores episódios de expropriação de suas terras e do silenciamento de suas vozes e línguas. Segundo Oliveira $(2001$; 2014), os chamados "caboclos da terra", especialmente os nativos do norte da Bahia e do sertão de Pernambuco, região fronteiriça cuja separação geográfica é delimitada pelo Rio São Francisco (denominado de Opará pelos Cariri, povos nativos da região, extintos no final do século XIX, de acordo com Lowie (1946) e referendado por Andrade (2012)), foram as principais vítimas do preconceito nestes dois importantes períodos históricos. No primeiro momento, à época da chegada dos portugueses em suas caravelas, foram subjugados enquanto (sub)raça, escravizados, dizimados e/ou domesticados pelo euro-cristianismo, portanto, submetidos a um processo de quase extinção; e, posteriormente, no contexto da democratização do país, em meio a alguns processos sociopolíticos nebulosos da história moderna do Brasil (segunda metade do século XX), nações indígenas do Nordeste (incluindo os povos pataxó, kiriri, tuxá e remanescentes dos tupinambás) foram excluídas das decisões políticas, tiveram seus corpos apartados de seus territórios e sofreram violências epistêmicas em relação às suas existências, ancestralidades e culturas.

Denominados "falsos índios", pois já haviam "embranquecido" o suficiente para perderem a estereotipia ameríndia (OLIVEIRA, 2014), inúmeros povos originários do Nordeste sucumbiram à violência da colonização e da colonialidade. Embora seja importante ressaltar que os episódios de violência contra os indígenas encontravam uma relativa resistência, cada dia mais combativa, seja no âmbito físico-geográfico, seja nos espaços sociopolíticos. Os povos indígenas da região do Submédio São Francisco, à margem esquerda do leito fluvial mais importante da região, no lado pernambucano, aqui denominada de Região 
de Abrangência do Opará ${ }^{1}$ (RAO), são testemunhas desses processos de violência. Ao mesmo tempo que são, também, protagonistas da luta pela preservação de suas culturas, seus saberes, suas línguas e modos de viver (SILVA, 2014), o que inclui, efetivamente, a retomada de territórios e a apropriação do sistema educacional.

Neste estudo, por abordar majoritariamente o campo teórico da educação, eu procuro defender que a Educação Escolar Indígena (EEI) funciona como um moto-contínuo desse contexto de luta, ao ser, ao mesmo tempo, um elemento de conquista e um instrumento para outras batalhas, inclusive no campo ideológico, que envolve as ciências, a legalidade (constitucionalidade) e a inclusão. E, para além do enfoque sobre a educação básica, em que a conquista de uma educação diferenciada está praticamente consolidada nas aldeias, o acesso aos cursos de graduação e pós-graduações, em diversos níveis, têm proporcionado aos indígenas locais, a construção de uma nova episteme, voltada ao embate mais politizado, consciente de seus direitos e de sua importância para a construção de uma efetiva Educação Escolar Indígena Intercultural.

A proposta inicial deste estudo é analisar marcas e concepções nos discursos presentes na produção acadêmico-científica e artístico-cultural dos professores-pesquisadores indígenas, em formações e capacitações desenvolvidas nas instituições da RAO, evidenciando os cursos de Especialização em Educação Intercultural, oferecidos pelo IF Sertão Pernambucano campus Floresta, os cursos de capacitação e formação promovidos pelo Centro de Pesquisa em Etnicidades Opará, da Universidade do Estado da Bahia - UNEB, campus Paulo Afonso e a política pública denominada Ação Saberes Indígenas na Escola (promovida tanto pelo IF Sertão quanto pelo Centro Opará), que muito tem contribuído para a formação/capacitação de professores indígenas, produção de material didático específico e para a construção de uma epistemologia intercultural, que valorize os conhecimentos ancestrais e promova a "Educação Escolar Indígena e Intercultural na Região de Abrangência do Opará”, segundo os documentos do IF Sertão, no projeto do curso de Especialização em Educação Intercultural.

Ao compreender a dimensão dos processos formativos acontecidos e em curso na região, ainda que prejudicados em suas metodologias por conta da pandemia do Coronavírus (Covid-19), tive que incluir a Análise Documental, para melhor coleta/produção dos dados da pesquisa inicial, que seria constituída inicialmente apenas pela Revisão Bibliográfica e pela

\footnotetext{
1 A Região de Abrangência do Opará está aqui delimitada pelo território pernambucano composto pelas subdivisões Médio e Submédio São Francisco, por conterem municípios cujas dependências geográfica e econômica estão diretamente ligadas ao Opará (Rio São Francisco), que significa "rio-mar", nas línguas autóctones das comunidades indígenas locais, descendentes dos kariri.
}

162 Id on Line Rev. Psic. V.16, N. 59, p. 160-187, Fevereiro/2022 - Multidisciplinar. ISSN 1981-1179 
Pesquisa de Campo, em entrevistas com professores e estudantes dos programas mencionados.

A partir da Revisão Bibliográfica, com base nos estudos do hibridismo cultural (CANCLINI, 2006) e da Lei 11.645 (BRASIL, 2008), que discute o ensino da cultura indígena e africana no currículo nacional, pude identificar a presença de um movimento de ressignificação sociocultural e linguística, presente nos grupos indígenas pesquisados;

Durante a Pesquisa de Campo, pelo contato direto e/ou remoto com os integrantes das comunidades, especificamente professores e professoras indígenas que participaram/participam de cursos de formação/capacitação, ficou clara a importância e a necessidade das discussões em nível acadêmico para o protagonismo indígena, tanto no processo pedagógico quanto na produção didático-científica; e

A Análise Documental, baseada em documentos do curso de Especialização em Educação Intercultural, oferecido pelo IF Sertão Pernambucano - campus Floresta, e dos cursos de capacitação e formação oferecidos pelo Núcleo Opará, da UNEB - campus Paulo Afonso, possibilitou-me conhecer e analisar as pesquisas desenvolvidas pelos professores e professoras indígenas, muitos deles, participantes da Ação Saberes Indígenas na Escola e de outros cursos oferecidos pelas instituições locais.

Os resultados da pesquisa, de caráter quali-quantitativo, estão alicerçados na Análise do Discurso (MAINGUENEAU, 2010), visto que é preciso compreender elementos da subjetividade, muitas vezes, subentendidos nos textos dos professores/pesquisadores indígenas. Em uma análise etnocultural, torna-se imprescindível a contextualização dos sujeitos para se compreender o constructo das formações/capacitações, que, a partir da pesquisa empírica e da análise dos documentos disponibilizados, apresentam efeitos significativos para a EEI dentro do Território Etnoeducacional Serra Negra² .

\section{Protagonistas de suas próprias histórias}

Por necessidade de localização, utilizarei os nomes de locais (cidades, estados, rios) registrados pela geografia física atual, ainda que os nomes indígenas sejam anteriores a estes.

\footnotetext{
${ }^{2}$ Os territórios etnoeducacionais foram uma conquista dos povos indígenas em relação à constituição de seus sistemas de educação escolar específicos. Em Pernambuco, o Território Etnoeducacional Serra Negra ainda está em processo de implantação. Cada território precisa de uma comissão gestora composta por indígenas e entidades ligadas ao setor para elaborar um plano de ação educacional e de acompanhamento desses povos. Segundo a FUNAI (2018), trata-se de um projeto que busca atender as necessidades e especificidades dos índios, em suas comunidades.
} 
Quanto à delimitação territorial, utilizei como critério de inclusão a área denominada Região de Abrangência do Opará (RAO), cujo sistema educacional das aldeias indígenas encontra-se consolidado, tanto pela expressiva quantidade de alunos indígenas matriculados anualmente, quanto em relação ao número de professores, todos indígenas, com formação superior ou notório saber na área das artes e culturas indígenas. Como observação, pude perceber que quase a totalidade dos professores com curso superior completo possui também algum curso de especialização na área de educação.

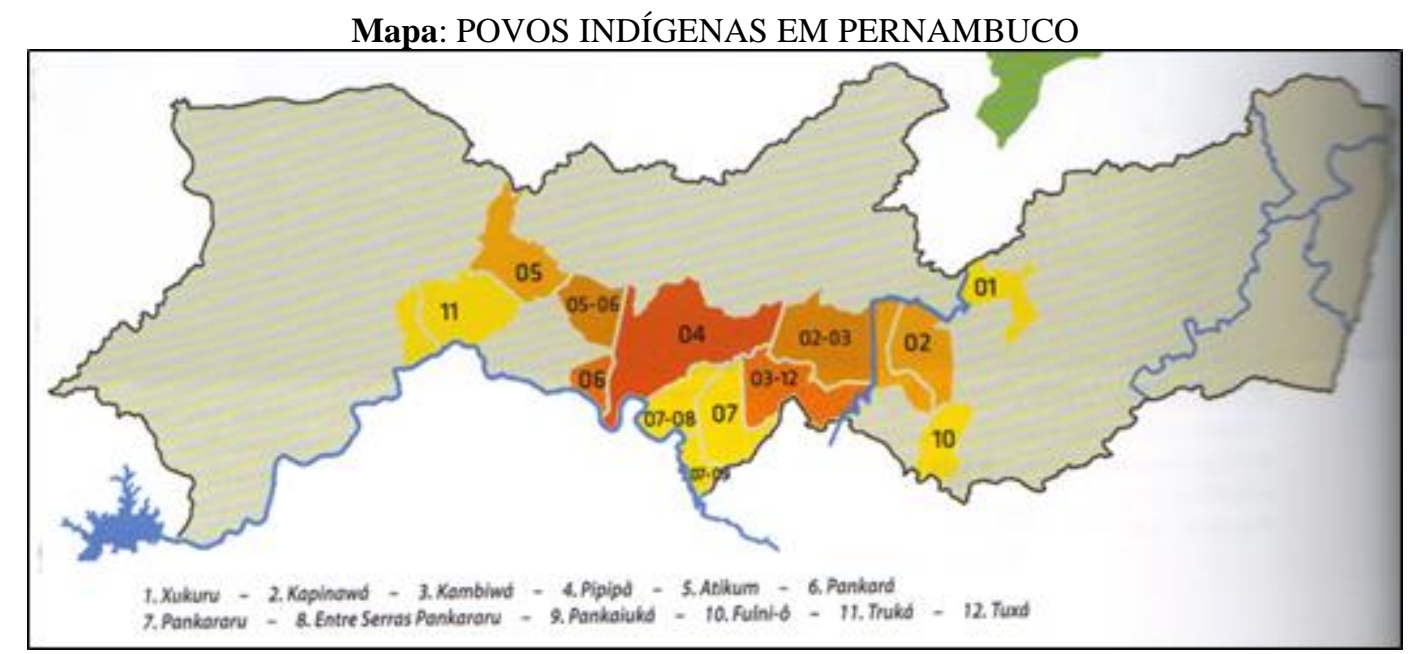

Fonte: COPIPE, 2019.

Portanto, foram escolhidas apenas três etnias localizadas no sertão pernambucano, entre as regiões do Médio e submédio São Francisco. Não seria uma amostragem pequena, visto que, no estado de Pernambuco, existem 12 povos indígenas (Xukuru (com o desmembramento em dois grupos), Kambiwá, Kapinawá, Tuxá, Fulni-ô, Pankará, Pankararu, Pankaiwka, Entre Serras, Pipipã, Atikum e Truká), e as etnias presentes no território do semiárido pernambucano, com significativo número de indivíduos são apenas seis: Pankararu, Pankaiwka, Entre Serras, Pipipã, Atikum e Truká. A escolha das comunidades Pankararu, Atikum e Truká se deu por possuírem as maiores populações, tratando-se de grupos específicos, com costumes relativamente muito aproximados e efetiva relação de interdependência com o Rio São Francisco (Opará).

Com uma população pouco superior a 56 mil indivíduos, distribuída entre aldeados em diversas regiões do Estado e sem contabilizar os indígenas não aldeados ou não declarados, há registros de 26 etnias em todo estado de Pernambuco, divididos em 12 povos, 
excetuando-se a subdivisão dos Xucuru (Xucuru de Ororubá e Xucuru de Cimbres) e o povo Tuxi, em processo de autoafirmação e reconhecimento (COPIPE, 2019).

\begin{tabular}{|l|c|l|}
\hline Povos/Núcleo Populacional /Aldeias & POPULAÇÃO & \multicolumn{1}{|c|}{ LOCALIZAÇAO/MUNICÍPIOS } \\
\hline Atikum & 4.631 & Carnaubeira da Penha e Salgueiro \\
\hline Fulni-ô & 4.260 & Águas Belas \\
\hline Kambiwá & 2.911 & Ibimirim e Inajáa \\
\hline Kapinawá & 3.283 & Buíque, Tupanatinga e Ibimirim \\
\hline Pankaiwcá & 150 & Jatobá \\
\hline Pankará & 5.300 & Carnaubeira da Penha e Itacuruba \\
\hline Pankararu & 5.500 & Petrolândia, Tacaratu e Jatobá \\
\hline Pankararu Entre Serras & 1.500 & Petrolândia, Tacaratu e Jatobá \\
\hline Pipipã & 1.195 & Floresta \\
\hline Tuxá & 261 & Inajá \\
\hline Truká & 6.236 & Cabrobó e Orocó \\
\hline Xukuru do Ororubá & 12.000 & Pesqueira e Poção \\
\hline Xukuru de Cimbres & $880^{3}$ & Alagoinha, Pedras, Pesqueira e Venturosa \\
\hline Tuxi & - & Belém de São Francisco. Em processo de \\
& & autoafirmação e reconhecimento \\
\hline
\end{tabular}

Fonte: COPIPE, 2019.

Entre os povos indígenas de Pernambuco, destacam-se dois importantes temas de pesquisas recentes: o povo Fulni-ô, da região Agreste do estado (município de Águas Belas), como a única comunidade da região nordeste setentrional a utilizar o seu idioma ancestral (o Ia-tê ou Yathê); e os povos da RAO, que apresentam o maior número de territórios demarcados e de populações indígenas aldeadas do estado, cujas comunidades apresentam um avançado processo de interculturalidade da EEI, no entanto, não reconhecem as línguas autóctones em sua oralidade (SECADI, 2018), por isso, não fazem uso da prerrogativa da Lei 11.645/2008, que versa sobre o ensino bilíngue nas escolas indígenas. Embora estudos nessa área começam a ser desenvolvidos pelos professores e pesquisadores das comunidades e, dentro das escolas, os Projetos Político-Pedagógicos (PPP) passam a abordar o tema.

Uma conquista recente é a divisão de áreas sociopolíticas para a educação indígena, no intuito de organizar a EEI nos contextos das comunidades locais. As delimitações de Territórios Etnoeducacionais é uma perspectiva atual de regularização e regulamentação promovido pela Secretaria de Educação Continuada, Alfabetização, Diversidade e Inclusão (SECADI), do Ministério da Educação (MEC). Instituído pelo Decreto de $\mathrm{N}^{\circ} 6.861$, de 2009, o Território Etnoeducacional é um espaço de planejamento e de gestão dos programas e das ações do governo voltados para os índios. O território é um local demarcado que funciona além das divisões políticas e geográficas. Une a iniciativa federal, estadual, municipal e de

${ }^{3}$ Censo demográfico realizado pela FUNASA em 2010. 
outras entidades dentro do mesmo objetivo de atender as especificidades educacionais dos povos indígenas (SECADI, 2009). Através dessa organização, o espaço das comunidades formadas por índios passa a ser definido de acordo com as relações sociais e históricas de cada grupo.

\section{Povos indígenas do Opará}

Pelo número de indígenas e, consequentemente, de indivíduos ligados à educação, professores e estudantes, em uma situação organizacional da EEI mais definida, foram incluídos nesta pesquisa os três povos indígenas mais representativos da RAO:

a) o povo Atikum, que atualmente habita o Território Indígena Atikum do atual município de Carnaubeira da Penha, no Sertão Pernambucano, após emancipação política do município de Floresta, em 1991. O então distrito tem história de fundação datada de 1896 e sua comunidade indígena exerce certa influência sobre os demais povos tradicionais locais (indígenas e quilombolas) pelo nível de organização do seu sistema educacional. Ainda que se localize a cerca de $50 \mathrm{~km}$ do leito do Opará, a comunidade tem estreita ligação com rio devido aos constantes deslocamentos empreendidos pelo seu povo no decorrer de sua história (BARROS, 2018). Faz parte da região denominada Submédio São Francisco - os chamar Itaparica, mesmo nome da vila operária (da CHESF) e da barragem (antes Itaparica, atualmente Luiz Gonzaga), construída no leito do São Francisco para produção de energia hidroelétrica;

b) as aldeias do povo Pankará, vizinho dos Atikum, ocupam territórios dos municípios de Carnaubeira da Penha e Floresta, e também possuem forte dependência das águas do Rio São Francisco, seja para consumo humano ou para atividades da agropecuária de subsistência, através de adutoras e canais de irrigação. No entanto, essa etnia, assim como as demais, no processo de nomadismo imposto pelas perseguições seculares, deslocou-se e fixou outros aldeamentos. Um exemplo desse deslocamento foi o quase total abandono de sua terra originária, a Serra do Arapuá (Floresta), com sérios problemas de insegurança alimentar devido às intempéries da seca, e o surgimento das aldeias em Itacuruba, às margens do Opará. Atualmente, os Pankará ocupam a Serra do Arapuá, em um movimento de retomada e ressignificação sociocultural. A aldeia de Itacuruba é chamada de ponta de rama, segundo 
riachos que banham seu território são afluentes do rio - e, recentemente, sua Gerência Regional de Educação (da Secretaria de Educação do Estado de Pernambuco) passou a se

Oliveira (2021), cuja mistura com quilombolas e outras etnias indígenas, inclusive do norte da Bahia, é evidenciada. Além disso, é possível identificar a presença de indígenas da etnia Pankará em diversos municípios do sertão pernambucano, além de Floresta, Carnaubeira da Penha e Itacuruba, também em Jatobá e Petrolândia, além de municípios do norte baiano; e

c) O povo Truká, provável corruptela linguística de Turká, e que, em suas duas grandes aldeias do lado pernambucano do rio, abrigam aproximadamente 6 mil indivíduos, distribuídos entre a Aldeia Indígena da Ilha da Assunção (ou Aldeia Mãe de Truká), no rio São Francisco, localizado na cidade de Cabrobó-PE, e Aldeia Truká Tapera, na Ilha de São Félix, município de Orocó-PE. Assim como as demais etnias, o povo Truká sofreu desapropriação de suas terras ancestrais e, nas migrações, estabeleceu outras aldeias, no caso: a comunidade de Tapera (Orocó), Truká Tupan (em Paulo Afonso-BA) e Truká Camixá (em Sobradinho-BA), segundo Batista (2004). Os indígenas chegaram à Ilha da Assunção em meados do século XVIII, com fatos narrados em diversos documentos, cartas e registros que historiam a sua fundação entre os anos de 1720 e 1770, marcada pela missão católica de Nossa Senhora da Assunção e a construção de uma igreja no ano de 1792 (BATISTA, 2004; 2009; ALMEIDA, 2003; 2010; SANTOS, 2016). Após serem “dominados" e "expulsos" pelas oligarquias do Estado, da Igreja e da classe rica, representada por políticos e grandes fazendeiros, os Truká só conseguiram reaver o seu território em sangrentas batalhas que culminaram em 1999, em um episódio que ficou conhecido como a Quarta Retomada, com a total expulsão dos fazendeiros e criadores de gado. Naquele momento, houve diversos conflitos entre indígenas e não-indígenas, o que gerou uma onda de violência sem precedentes, o que gerou uma interdição das forças de segurança estaduais. Depois de reconquistada, a ilha teve o seu acesso controlado pelos Truká. Segundo o Cacique Bertinho Truká, em entrevista em março de 2016, “os Truká tiveram que fechar a entrada da ilha para se proteger de tudo que era ruim".

\section{Políticas públicas e ações afirmativas}

Desde o início da pesquisa, busquei construir uma análise paradigmática acerca das concepções e práticas da EEI nas aldeias da RAO e compreender o seu papel em relação às possibilidades de reconhecimento linguístico-cultural, dentro do processo de ressignificação 
sociocultural dos povos indígenas, em construção nas aldeias do Opará. As confluências entre as propostas da pedagogia decolonial e as políticas públicas de reformulação curricular, tendo como referência as Diretrizes Curriculares Nacionais para a Educação das Relações ÉtnicoRaciais e para o Ensino de História e Cultura Afro-Brasileira e Africana (BRASIL, 2012), aparecem nas propostas da EEI e no interesse local de se efetivar uma produção didáticocientífica intercultural. O que é potencializado pelos cursos de formação e capacitação, oferecido pelas instituições de abrangência local.

Por isso, como objetivo desse estudo, tornou-se essencial evidenciar a produção acadêmica (científica, artística e didática) dos indígenas da RAO, nesse processo de ressignificação sociocultural. Assim, na luta pela preservação dos povos e saberes tradicionais, e como demanda dos movimentos indígenas, surgem diversas políticas públicas, em nível nacional e local, cujos objetivos de criação/produção didático-científica, ultrapassam as barreiras do sistema educacional e criam uma nova epistemologia do fazer ciência e, consequentemente, do fazer educação.

Neste estudo, são abordadas três ações afirmativas, com ênfase nos trabalhos desenvolvidos pela Universidade do Estado da Bahia (UNEB) e pelo Instituto Federal de Educação, Ciência e Tecnologia do Sertão Pernambucano (IF Sertão):

a) o Centro de Pesquisa em Etnicidades, Movimentos Sociais e Educação Opará, da Universidade do Estado da Bahia (UNEB), campus Paulo Afonso-BA, coordenado pela professora Msc. Floriza Maria Sena Fernandes, que orienta a Ação Saberes Indígenas na Escola, além de cursos de capacitação e formação de professores e lideranças indígenas e quilombolas, tem como área de abrangência a região do Opará do território baiano, no entanto, atende os povos indígenas do estado de Pernambuco, a saber: Atikum, Fulni-ô, Pankará, Pancararus e Truká;

b) o Instituto Federal de Educação, Ciência e Tecnologia do Sertão Pernambucano, campus Floresta, sob coordenação da professora Msc. Edivânia Granja da Silva Oliveira, também responsável pela Ação Saberes Indígenas na Escola, no estado de Pernambuco, que já ofereceu dois cursos de especialização voltados ao público indígena e quilombola: Especialização em Educação Indígena e Quilombola e Especialização em Educação Intercultural - indígenas e quilombolas; e

c) a Ação Saberes Indígenas na Escola, uma política pública em nível nacional, como ação afirmativa na área educacional, fomenta, através de universidades públicas e institutos federais de educação, cursos de capacitação e formação para os povos originários, incluindo a 
publicação de material escolar, livros didáticos e paradidáticos, produzidos pelos próprios indígenas.

\section{Produção didático-científica dos povos indígenas do Opará}

As lutas dos povos indígenas sempre se direcionaram para "lutas por terra", seja demarcação, identificação de territórios indígenas (T.I.), ou simplesmente, ocupação, o que é seria irônico se não fosse trágico, uma vez que os povos indígenas são os verdadeiros donos das terras (SILVA, 2014). Mas não só as lutas pela terra, caracterizam o dia a dia dos povos indígenas, as questões identitárias também se somam a estas e se tornam dinâmicas da resistência indígena; essas lutas trazem consigo um potencial emancipatório a partir de demandas baseadas em relações específicas com a terra, com os ecossistemas, do cuidado com a saúde e por uma educação emancipatória e cidadã. Dentre esses mecanismos de luta, os indígenas, em diferentes níveis, pelo Brasil adentro, têm feito uso do sistema educacional no processo de ressignificação sociocultural.

No século XXI, a EEI tem se tornado uma das frentes de batalha dos povos indígenas brasileiros, essencial tanto para a preservação dos saberes indígenas - não sistematizados e pelo próprio enfoque cultural que possui -, quanto na produção do hibridismo cultural, natural aos manejos socioculturais na história da humanidade (CANCLINI, 2010).

Uma das conquistas da EEI, a Lei 11.645/2008 (BRASIL, 2008), conhecida como Lei do Ensino Bilíngue, apregoa: "Nos estabelecimentos de ensino fundamental e de ensino médio, públicos e privados, torna-se obrigatório o estudo da história e cultura afro-brasileira e indígena" (Art. 26-A). No entanto, para os povos nativos, isto não é suficiente, percebe-se entre os indígenas, a necessidade de aprimorar seus estudos, elevando o nível dos discursos nas aldeias. Essa nova realidade desencadeia pesquisas desenvolvidas pelos próprios indígenas, a partir dos saberes e fazeres indígenas, saindo do lugar de 'pesquisados' ou 'objetos de estudo', para o lugar de pesquisadores, historiando suas culturas, valorizando suas territorialidades e os diversos aspectos de suas existências, seja mística, afetiva, artística, econômica etc.

Aos poucos, vão surgindo no currículo das escolas indígenas e, mais ainda, nas práticas didáticas dos professores que fazem a EEI, livros e produtos direcionados especificamente a essa demanda. Muito desse material, físico e digital, é produzido pelos próprios indígenas, na condição de protagonistas do fazer pedagógico nas escolas indígenas 
em todo o Brasil. Na região do submédio São Francisco, área de abrangência do semiárido nordestino, entre os estados de Pernambuco e Bahia, essas ações vêm sendo promovidas pelos povos indígenas e recebendo apoio das principais instituições locais de ensino superior, em especial da Universidade do Estado da Bahia (UNEB), através do Opará (Centro de Pesquisa em Etnicidades, Movimentos Sociais e Educação) e do Instituto Federal de Educação, Ciência e Tecnologia do Sertão Pernambucano (IF Sertão), com a implementação de cursos de especialização, com foco na educação intercultural.

O Centro Opará, da Universidade do Estado da Bahia, com sede no campus Paulo Afonso e núcleos nos campi Euclides da Cunha e Juazeiro, desenvolve junto às comunidades indígenas do estado da Bahia (Atikum, Kaimbé, Kantaruré, Kiriri, Pankaru, Pankararé, Pataxó, Pataxó Hã-Hã-Hãe, Payayá, Truká, Tumbalalá, Tupinambá, Tuxá e Xukuru-Kariri) (ISA, 2015), diversos projetos de formação e capacitação dos professores indígenas, incluindo o Programa Saberes Indígenas na Escola, do qual participam também povos do estado de Pernambuco, principalmente os indígenas das etnias Fulni-ô, Pankará, Atikum e Truká. Com exceção do povo Fulni-ô, as demais aldeias estão alocadas na área de abrangência do Rio São Francisco.

Entre os povos indígenas participantes, graduandos e pós-graduandos, percebe-se uma inquietação acerca da investigação acadêmica da sua própria pesquisa, ou seja, há um devir investigativo se instaurando no fazer-se acadêmico, que objetiva o fazer-se pesquisador. Por isso, os trabalhos etnográficos, não somente como prospecção do conhecimento, é uma constante na produção dos participantes do centro Opará, uma vez que registra nuances, sentimentos e comportamentos de culturas autóctones, tão importantes para o reconhecimento de uma epistemologia ativa, em constante questionamento.

A um etnógrafo é requerido despender um tempo significativo no campo, imergindo nas vidas dos sujeitos objetos do estudo e tentando colocar o fenômeno estudado em seu contexto social e cultural (SIMONI; BARANAUSKAS, 2003), seguindo essa linha de pensamento, ninguém melhor que os próprios indígenas para narrarem sua história. Esse procedimento, que se trata de um processo em construção na região estudada, pode contribuir para superar os vazios que permanecem no campo dos estudos culturais e que, muitas vezes, reeditam falhas pois, é de difícil compreensão estudos culturais com grupos portadores de especificidades. O que pode resultar em interpretações equivocadas, com sérias consequências tanto para a ciência, que se 'autoproduz' em um processo endógeno, como para as formas de intervenção, que são propostas sobre a realidade desses povos. Dessa forma é legítimo que os 
indígenas, por serem parte de sociedades que apresentam especificidades culturais próprias a cada povo, desejem eles mesmos serem os etnógrafos de seus saberes. Os protagonistas de suas próprias pesquisas.

Dialogando com Canclini (2010), podemos afirmar que todos os povos, grupos, regiões e culturas reivindicam um lugar próprio e singular; isto não é um debate novo. A questão da diversidade e do contato cultural sempre esteve presente na humanidade e, agora, coloca-se de modo intenso nas sociedades modernas, particularmente nos centros de produção do conhecimento, fazendo emergir um intenso debate em torno da produção do conhecimento, de seu alcance e de seus limites, de modo a questionar as formas constituídas de saber. O que se constitui um exercício de descolonização para os povos tradicionais, historicamente excluídos dessas possibilidades de construção social.

Neste estudo, procuro mostrar os esforços das instituições locais de ensino, pesquisa e extensão, com preocupações nessas questões de territorialidades e hibridismo cultural, que propõem importantes propostas na perspectiva de descolonização do saber científico.

\section{Centro de Pesquisa e Etnicidades Opará}

O Centro Opará, atualmente, é responsável por dois cursos de graduação voltados aos povos tradicionais na região do Rio São Francisco, entre os estados de Pernambuco e Bahia: a Licenciatura Intercultural (LICEEI) e a Licenciatura em Pedagogia Intercultural Indígena). O centro promove ainda cursos de formação continuada da Ação Saberes Indígenas, Assessoria de Comunicação dos Povos Indígenas do Norte Baiano, Laboratório de Prática Pedagógica e Produção de Material Didático, Periódico Científico (Revista Opará, ISSN 2317-9465) e dois cursos de pós-graduação lato-sensu: a Especialização em Educação Intercultural e o curso de Gestão Escolar Indígena. Em nível stricto-sensu, o Opará, em parceria com o campus 1, da Universidade do Estado da Bahia (UNEB), em Salvador, oferece em Paulo Afonso, o Mestrado do Programa de Pós-graduação em Estudos Africanos, Povos Indígenas e Culturas Negras.

Embora o Opará seja reconhecido como Centro Estratégico para Políticas Indigenistas no âmbito da Universidade do Estado da Bahia no atendimento aos povos do norte e oeste do Estado pelos projetos que desenvolve, pela presença forte de pesquisadores, pesquisadoras indígenas e indigenistas, e sobretudo pelo sentimento de pertencimento que os povos indígenas destes territórios sentem em relação a este espaço acadêmico, também agrega

171 Id on Line Rev. Psic. V.16, N. 59, p. 160-187, Fevereiro/2022 - Multidisciplinar. ISSN 1981-1179 Edição eletrônica em http://idonline.emnuvens.com.br/id 
prática, princípios e ações na perspectiva de fortalecer e incentivar a pesquisa, extensão e formação continuada junto a outros povos e comunidades tradicionais e os movimentos sociais, valorizando suas lutas, contribuindo para o fortalecimento em relação à afirmação, conhecimento, valorização dos costumes e saberes, sustentabilidade, conservação de patrimônios culturais e imateriais, além dos patrimônios naturais que compõem as paisagens do semiárido, segundo seu projeto inicial (UNEB, 2013), como se encontra exposto no site do Centro:

Surgiu em 2008 a partir de um grande encontro de pesquisadores, pesquisadoras, estudantes, representantes dos Povos Indígenas e Comunidades Tradicionais com o objetivo de tornar-se um espaço acadêmico capaz de fortalecer, incentivar as pesquisas, a formação continuada e dinâmica dos Povos Tradicionais, Indígenas e lideranças de Movimentos Sociais em relação à afirmação, conhecimento e valorização dos seus saberes e fazeres, como forma de empoderamento das identidades e dos seus patrimônios bioculturais, contribuindo assim para uma permanente construção da cidadania ativa, de uma prática social que promova a cultura dos direitos humanos para todos os setores da sociedade. Sob essa ótica, o Centro de Pesquisas em Etnicidades, Movimentos Sociais e Educação - OPARÁ foi legalizado dentro da UNEB acordo com a Resolução CONSU N. ${ }^{\circ} 1010$ de $1^{\circ}$ de Setembro de 2013, bem como seu Regimento Interno é aprovado pelo Conselho Superior através da RESOLUÇÃO No 1.204/2016

Sustentado na tríade Ensino, Pesquisa e Extensão o OPARÁ-UNEB, através de suas linhas de pesquisas, desenvolve projetos na perspectiva de promover a qualificação de professores, pesquisadores, profissionais indígenas, quilombolas e trabalhadores rurais, oferecendo cursos de formação continuada e de pós - graduação intercultural a fim de fomentar experiências de pesquisas, sistematização, registro de práticas e conhecimentos tradicionais, a partir do princípio da autoria, bem como produzir material didático para uso em suas escolas. Busca também através de projetos de capacitação estimular a gestão territorial com ações que integram experiências de uso, manejo e conservação dos recursos naturais para garantir a integridade e uso sustentável de seus territórios (www.oparauneb.com).

Em 13 anos de atuação, o Centro Opará contribuiu/contribui para a formação de professoras e professores indígenas em ações educativas promovidas dentro e fora das aldeias. O Opará possui atualmente 27 pesquisadores institucionais (do quadro efetivo da UNEB), com mestrado e/ou doutorado, entre os quais, quatro são indígenas; 14 pesquisadores visitantes (incluindo 4 indígenas); 11 projetos de extensão e 24 projetos de pesquisa em andamento. O Centro tem como uma de suas prioridades a produção e difusão do conhecimento científico para a comunidade externa e acadêmica com material impresso e/ou digital (on-line), acessível ao público, que possa contribuir para a formulação de dados e conhecimento aproximado da realidade de suas linhas pesquisas. Assim, três ações são 
contempladas por essa perspectiva de publicação: em nível da educação básica, os livros didáticos e paradidáticos; e os livros de caráter técnico-científico, através do LAPRAXIS (Laboratório de Ensino e Pesquisa para Relações Étnico Raciais e Movimentos Sociais), auxiliando as Licenciaturas Interculturais e Pós-Graduação na produção, elaboração e circulação de material didático contextualizado e produzido pelos próprios professores indígenas, quilombolas e/ou do campo; e o apoio aos pesquisadores para a publicação de artigos em periódicos científicos, incluindo a própria revista Opará.

A Ação Saberes Indígenas na Escola é um projeto criado pela SECADI/MEC em rede Nacional de Instituição de Ensino Superior que busca promover a formação continuada de professores da EEI, especialmente daqueles que atuam nos anos iniciais da educação básica; oferecer recursos didáticos e pedagógicos que atendam às especificidades da organização comunitária, do multilinguismo e da interculturalidade que fundamentam os projetos educativos nas comunidades indígenas; oferecer subsídios à elaboração de currículos, definição de metodologias e processos de avaliação que atendam às especificidades dos processos de letramento, numeramento e conhecimentos dos povos indígenas; fomentar pesquisas que resultem na elaboração de materiais didáticos e paradidáticos em diversas linguagens, bilíngues e monolíngues, conforme a situação sociolinguística e de acordo com as especificidades da educação escolar indígena.

No Estado da Bahia, a Ação é coordenada pela UNEB através do OPARÁ em parceria com o Instituto Federal de Educação - IFBA de Porto Seguro e a Coordenação de Educação Indígena da Secretaria de Educação do Estado da Bahia, além das Coordenações dos Núcleos Regionais de Educação. A Ação acompanha até o momento a formação continuada de 15 povos indígenas: Atikum, Kaimbé, Kantaruré, Kiriri, Pankararé, Pataxó, Pataxó Hã-hã-hãe, Truká Tupan, Tumbalalá, Tupinambá, Tuxá, Xucuru-Kariri, Tuxí, Pankaru, e Fulni-ô no estado de Pernambuco, totalizando em 2019 mais de 542 professores indígenas com um alcance médio de 3.000 alunos da educação básica. No Estado de Pernambuco, a Ação é coordenada pelo Instituto Federal de Educação, Ciência e Tecnologia do Sertão Pernambucano (IF Sertão-PE), e, por uma questão de proximidade geográfica, o programa ficou sediado no Campus Floresta.

Sob a coordenação da professora MsC. Edivânia Granja da Silva Oliveira, a Ação Saberes Indígenas na Escola tem atendido aos povos indígenas da RAO, entre os anos de 2014 a 2020, com cursos de formação continuada nas aldeias ou no campus Floresta do IF Sertão. Segundo o responsável local, professor Msc. João Luiz da Silva, o programa tem 
atendido professoras e professores de 35 comunidades indígenas locais (IFSERTÃOPE, 2020).

\section{Cursos de Especialização do IF Sertão Pernambucano}

O IF Sertão Pernambucano tem se destacado no desenvolvido de ações de formação e capacitação dos professores e professoras indígenas da RAO, oferecendo, inclusive cursos de pós-graduação lato-sensu. Desde 2014, foram ofertados os seguintes cursos: Especialização em Educação Intercultural e Especialização em Interculturalidade e Decolonialidade na Educação Escolar Indígena e Quilombola. Atualmente, em 2021, o Instituto está promovendo uma reestruturação do Curso de Especialização em Educação Intercultural, cujo projeto é fruto da coletividade, em que participam professores do IF Sertão, juntamente com pesquisadores de instituições parceiras, lideranças e professores indígenas.

Como o título reformulado, o atual curso de Pós-Graduação Lato Sensu em "Educação Intercultural no Pensamento Decolonial" - modalidade Especialização - destina-se a atender as demandas de formação continuada/permanente preferencialmente de profissionais de educação pertencentes aos povos indígenas e comunidades quilombolas do estado de Pernambuco, embora esteja igualmente destinado a educadores/as indígenas e quilombolas de estados circunvizinhos, assim como a profissionais de educação que atuem em instituições educativas que prestem serviços educacionais a tais populações. De acordo com os documentos do curso:

A presente proposta visa, em seu potencial político-pedagógico, contribuir à superação dos desafios ético-políticos que se apresentam às políticas públicas de educação nesta região, a saber: a invisibilidade, nestas, da ampla diversidade étnico-racial da região, efeito da injustiça cognitiva e curricular que caracteriza a história social e político-econômica das relações entre o Estado e estes grupos sociais neste território. Tais desafios solicitam arranjos formativo-investigativos capazes de plena interação colaborativa, na qual professores/as, lideranças e anciãos/ãs, pesquisadores/as e sociedades reúnam-se no desenvolvimento e estabelecimento loco-regional - simultaneamente político e científico - da Cidadania Intercultural (Mato, 2008, 2009a, 2009b, 2010) e da Ecologia dos Saberes (Santos, 2010) (IF SERTÃO PERNAMBUCANO, 2014).

A existência de demanda social regional por cursos de formação continuada para professore/as indígenas e quilombolas apresentou-se formalmente ao Instituto Federal de Educação, Ciência e Tecnologia do Sertão Pernambucano (IF Sertão PE) no segundo semestre 
do ano de 2010, durante uma visita de professores/as-pesquisadores/as do grupo de pesquisa GMEPEIS Sertões - Grupo Multidisciplinar de Estudos e Pesquisas em Educação, Interculturalidade Crítica e Sociedades Sertanejas - a educadores/as e escolas do povo Pankará, situadas na Serra do Arapuá, no município de Carnaubeira da Penha, vizinho à cidade de Floresta, que sedia um dos campi da instituição (IF SERTÃO PERNAMBUCANO, 2014).

Segundo relatos dos coordenadores, naquela oportunidade, foram informados do expressivo número de professore/as indígenas e quilombolas que, na região, já haviam concluído graduações em instituições privadas presentes nos municípios circunvizinhos ou participavam da Licenciatura em Educação Intercultural para professores/as indígenas, sediada na UFPE/Campus Agreste, na cidade de Caruaru, e procuravam cursos de Especialização na área da EEI. Ainda, segundo as lideranças locais, Pankará, Atikum e Truká, o cenário da demanda de formação de professores/as indígenas e quilombolas apresenta, além de evidentes dimensões quantitativas, profundas dimensões qualitativas, pois boa parte das experiências formativas destes/as educadores/as, ao se dar em instituições de ensino superior/profissional de cultura organizacional e epistemológica monocultural (ocidentaleuropeia e capitalista) (CANDAU; RUSSO, 2010; OLIVEIRA; CANDAU, 2010), acaba por não ser plenamente útil ao projeto de educação indígena diferenciada.

Ao romper os padrões de pesquisa tradicionais, esses novos pesquisadores, apropriando-se do papel de sujeitos produtores de conhecimento teórico-científico e conscientes da necessidade de protagonizar novas teorias e metodologias, procuram romper uma das estruturas mais cristalizadas pelo grupo social em que está inserida, que é a pesquisa científica no mundo acadêmico. Os indígenas ingressaram de maneira decisiva no âmbito da produção científica local, e apesar de demasiadamente endógena, vem contribuindo substancialmente para, assim como os objetivos desta pesquisa, realçar os discursos presentes nos estudos desenvolvidos por professoras/es (pesquisadoras/es) indígenas do tempo presente, especificamente, no território etnoeducacional da Serra Negra, ou seja, na Região de Abrangência do Opará (RAO). É notória a imaturidade na análise dos dados e até mesmo nas metodologias de busca e construção dos dados empíricos. No entanto, o trabalho vem sendo realizado e, de forma intercultural, tem trazido novas aprendizagens para todos os grupos envolvidos.

Portanto, apresento a seguir alguns pontos de vista e suas respectivas análises dos trabalhos finais dos cursos, totalizados em 12 concluintes da primeira turma (Especialização 
em Educação Intercultural para o Pensamento Decolonial) e 11 da segunda turma (Especialização em Educação Intercultural - Indígenas e Quilombolas), entre os anos de 2015 e 2020. Ao analisar as produções das professoras e professores indígenas, egressos do curso, optei por apenas três trabalhos no universo de 12 (visto que alguns trabalhos foram escritos em duplas e trios), contemplando as três etnias mais presentes no curso (Atikum, Pankará e Truká), utilizando como base de compreensão a Análise do Discurso, a partir dos estudos de Maingueneau (2012).

\section{A etnografia indígena e os desafios comuns à pesquisa}

Os saberes indígenas são conhecimentos tradicionais milenares que necessitam ser valorizados, reconhecidos e inseridos nos processos educativos da Educação Escolar Indígena. $\mathrm{O}$ que mantém viva a sabedoria da nova geração indígena é provavelmente a valorização da cultura do seu povo, que é constantemente difundida entre as comunidades autóctones com o propósito de garantir que as tradições e o aprendizado sejam utilizados desde o mais novo vivente indígena e a escola não pode estar fora deste processo de construção do conhecimento. O aprender, o ensinar, e principalmente, o projetar para o engajamento político com a terra-pátria, é a afirmação comum dessa diversidade, e esse lugar privilegiado, como ambiente educativo e espaço de formação de pessoas é, sem dúvidas, o espaço escolar.

Nos trabalhos analisados, foi constatada uma visão comum sobre os espaços educacionais. A escola é construída por uma diversidade de atores que pensam e agem no cotidiano, formando uma rede de relações que se define com base em uma cultura própria e repleta de significados (SANTOS; SILVA, 2018). As "maneiras de fazer" a escola inserem-se nas práticas elaboradas no cotidiano escolar e fazem parte de um conjunto de ações coletivas, tornando cada realidade escolar única (PAJEÚ; FRANÇA, 2018).

O Trabalho de Conclusão do Curso de Especialização em Educação Intercultural no Pensamento Decolonial das alunas Lauane dos Santos e Vivência Maria da Silva ${ }^{4}$ aborda especificamente a relação entre a EEI e o processo de descolonização empreendido nas escolas da aldeia Truká, na Ilha da Assunção. As estudantes constroem reflexões na perspectiva de um povo que vem buscando, ao longo de anos e através de sua educação

\footnotetext{
${ }^{4}$ Monografia apresentada ao Instituto Federal de Educação, Ciência e Tecnologia do Sertão Pernambucano, como Trabalho de Conclusão do Curso de Especialização em Educação Intercultural para o pensamento decolonial, pelas alunas Lauane dos Santos e Vivência Maria da Silva, ano 2018.
} 
institucionalizada, libertar-se dos malefícios causados pelo processo de colonização. No texto, as autoras discutem a EEI "Específica e Diferenciada" em relação à percepção da história, dos movimentos de mobilização, valorização da cultura em um processo de ressignificação sociocultural empreendido pelo povo Truká. Ainda que lhes faltem comprovações através de dados empíricos, as estudantes-pesquisadoras propõem uma valiosa reflexão, proposta pela revisão de literatura sobre a temática.

Assim, como no trabalho intitulado "Desafios e Limites das Práticas da Gestão Escolar do Povo Truká"5, as estudantes Edilene Pajeú (Pretinha Truká) e Maria Eunice França discutem diferentes formas da gestão escolar em diálogo com os "saberes indígenas" como elemento constituinte da gestão e da organização escolar na EEI.

Nesses e nos demais trabalhos analisados, percebe-se uma inclinação natural dos discursos de valorização das culturas e dos saberes indígenas. Segundo Maingueneau (2012), os discursos são abstrações possíveis da fala. O que não difere da perspectiva de Bardin (2010), em que os discursos aparecem de forma explícita em palavras e expressões que, segundo a autora, no terceiro segmento de sua Análise do Conteúdo, já seria suficiente para identificar uma nova ordem discursiva a ser compreendida como mecanismo de desconstrução do pensamento institucionalizado pela colonização.

Dialogando com esses dois autores, é possível encontrar elementos comuns da análise nos textos analisados. Os discursos são descritivos, embora pouco pessoais, mas, emblemáticos dos povos indígenas regionais - a ausência do uso da língua nativa não os impede de reivindicar a presença dessas línguas em suas construções socioculturais. Maingueneau se propõe a uma investigação mais contextual, em que as intenções dos autores, muitas vezes, esbarram na impossibilidade de expressão, por motivos diversos. Pensando assim, procurei estabelecer o diálogo com esse autor, na análise dos textos que mais me chamaram a atenção na relação entre a teoria e a prática decolonial. O TCC defendido pela estudante Kauanne Laene da Silva Cabral propõe reflexões acerca da presença das línguas autóctones no consciente coletivo da população Truká, ao abordar outro importante elemento cultural do povo na EEI: o Toré. Intitulado "A importância do Toré para o fortalecimento

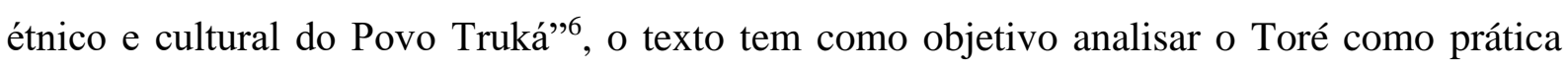

\footnotetext{
${ }^{5}$ Monografia apresentada ao Instituto Federal de Educação, Ciência e Tecnologia do Sertão Pernambucano, como Trabalho de Conclusão do Curso de Especialização em Educação Intercultural para o pensamento decolonial, pelas alunas Edilene Bezerra Pajeú e Maria Eunice Alventina da Silva França, ano 2018.

${ }^{6}$ Monografia apresentada ao Instituto Federal de Educação, Ciência e Tecnologia do Sertão Pernambucano, como Trabalho de Conclusão do Curso de Especialização em Educação Intercultural para o pensamento decolonial, pela aluna Kauanne Laena da Silva Cabral, ano 2020.
}

177 Id on Line Rev. Psic. V.16, N. 59, p. 160-187, Fevereiro/2022 - Multidisciplinar. ISSN 1981-1179 Edição eletrônica em http://idonline.emnuvens.com.br/id 
pedagógica na reafirmação sociocultural do povo Truká (CABRAL, 2020). O texto traz ainda uma compreensão particular da identidade étnico-cultural do povo Truká, a partir das reminiscências linguísticas imortalizadas nas linhas (toantes) do Toré, analisando o processo de constituição identitária, que tem por base histórica a colonização na região do Rio São Francisco e a dominação pela ganância capitalista. Segundo a autora, no curso da resistência, o povo conseguiu se reafirmar como coletividade indígena, mesmo tendo que enfrentar opressões e preconceitos, que perduram até os dias atuais.

O Toré, para o povo Truká, assim como para outros povos indígenas, ocupa um lugar de centralidade do cotidiano nas aldeias, obtendo, ao mesmo tempo, uma relevância social e política muito significativa (CABRAL, 2020). Ao tempo que é tratado como um exercício performático, religioso e sociocultural da maior importância para a coletividade dos povos indígenas em todo o Brasil.

No aspecto religioso-performático, os indígenas cultivam o elo com os encantados, com a ancestralidade, cultivando suas identidades; a dimensão política se encontra integrada à religiosa, pois a ligação com a tradição torna mais forte cada integrante do povo Truká, preparando-os para a luta, tendo em vista a preservação de sua cultura e a garantia de seus direitos fundamentais (CABRAL, 2020, p. 15).

O discurso da autora nos faz crer que, no ritual do Toré, a afirmação da identidade coletiva do povo Truká ocupa lugar de destaque, delineando uma tradição comum e trajetórias a serem percorridas. Nele, se afirmam projetos coletivos, que relacionam o presente com o passado e o futuro, sem perder de vista a tradição ancestral. As palavras, expressões e frases em línguas autóctones, cujos significados não são unânimes entre os próprios indígenas, apresentam a tentativa dessa manutenção sociocultural, assim como as prospecções de lutas. Dentre os direitos a serem conquistados ou garantidos, se encontra em destaque a terra/território, entendido como sagrado e fundamental para a existência de um projeto que atenda a todo o povo Truká.

A relevância do Toré para os povos Truká se encontra no poder de ser um elemento sagrado de preservação da identidade, profundamente relacionada à ancestralidade, e na organização religiosa, social e político desse povo, resultando na luta coletiva por seus direitos (CABRAL, 2020, p. 17).

Foi facultado aos estudantes dos cursos de especialização que apresentassem monografias ou artigos acadêmicos como Trabalho de Conclusão de Curso (TCC). O que se 
percebeu, a partir das análises dos discursos construídos por orientandos e orientadores foi o entrelaçamento de temas que defendiam ideias afins. Assim como Kauanne Cabral, ao defender o Toré como prática interventiva pedagógica e intercultural para a construção dessa reafirmação sociocultural dos povos indígenas locais, o trabalho da professora Atikum Maria da Penha Barros, que busca analisar as práticas do Bem Viver, também frisa importantes ações para a compreensão do ser índio para essas/nessas comunidades locais, tantas vezes desacreditadas pelos estereótipos vigentes.

O TCC intitulado Múltiplos Olhares para as Políticas Educacionais do Povo Atikum ${ }^{7}$ tem como objetivo principal, uma reflexão sobre as práticas do bem viver, a partir da coletividade do povo indígena Atikum. A aluna-professora Maria da Penha Barros desenvolveu sua pesquisa na mesma comunidade onde mora e leciona, cuja ideia central teve o objetivo de problematizar o respeito com o território como espaço sagrado e o cuidado com a mãe terra, tendo a consciência da necessidade de encontrar medidas práticas e urgentes no sentido de se viver bem e devolver o equilíbrio e a fertilidade da Mãe-Terra como projeto de vida, segundo a própria autora em entrevista em 04 de abril de 2019.

O pensar-sentir o território do povo Atikum aparece na monografia da autora a partir dos pressupostos encontrados no livro Caderno do Tempo, obra lançada pelo povo como material didático a ser trabalhado nas escolas indígenas da aldeia de Carnaubeira da Penha: "O tempo nos ensina que é preciso esperar a terra descansar para o solo preparar, a chuva chegar para a semente plantar e o fruto amadurecer para o homem colher" (COLETIVIDADE ATIKUM, 2006, p. 75).

Não apenas pelo sustento do qual necessitam para sobrevivência territorial e segurança alimentar, mas pelo sentimento de pertencimento tanto ao universo quanto ao seu povo, na valorização e sabedoria dos anciãos que são a "enciclopédia viva" do povo e guardiões da sabedoria do povo, mantendo assim uma relação de amor e respeito com a terra, segundo testemunho do cacique Augusto Agustavo, do povo Atikum, em entrevista realizada em maio de 2014.

\begin{abstract}
A terra para nós é como uma mãe que nos dá tudo sem nada pedir em troca, mas da mesma forma que cuidamos da nossa mãe que nos amamentou, também precisamos cuidar da nossa segunda mãe que é a terra e que é a nossa morada no espaço (COLETIVIDADE ATIKUM, 2006, s/p).
\end{abstract}

\footnotetext{
${ }^{7}$ Monografia apresentada ao Instituto Federal de Educação, Ciência e Tecnologia do Sertão Pernambucano, como Trabalho de Conclusão do Curso de Especialização em Educação Intercultural para o pensamento decolonial, pela aluna Maria da Penha Barros, 2018.
} 
Assim, o povo Atikum reconhece a terra como a reprodução da vida e não apenas como numa mercadoria destinada à produção de excedente para o mercado, mas para construção do futuro dos seus filhos, pois, os indígenas têm valores diferentes que a sociedade dos não índios. A floresta, por exemplo, é vista como a morada dos encantos de luz, que protegem e orientam os indígenas nas atividades cotidianas nas aldeias.

Segundo o discurso da professora indígena, "essa relação de amor e respeito é muito importante por isso ao praticar o ritual sagrado, faz-se com os pés descalços para receber as energias emanadas da mãe terra" (BARROS, 2018, p. 13).

Sobre a conservação do meio, os discursos atingem esse nível de envolvimento afetivo: “A exploração irracional atinge não só operários, indígenas ou (i)migrantes, também afeta a nossa irmã natureza, pela devastação de florestas e, consequentemente, da biodiversidade" (BARROS, 2018, p. 23).

A questão do bem viver está muito além do discurso sobre ecologia e sustentabilidade. A prática do bem viver, que faz parte do cotidiano dos povos indígenas, poderia servir de modelo para outras nações, segundo a Coletividade Atikum, em seu Caderno do Tempo (2006).

Não com isso que os indígenas sejam o dono da verdade absoluta sobre as práticas do bem viver, mas sim interlocutores privilegiados que, com sua vivência e intimidade com o ambiente, pode questionar e provocar reflexões. Nesse sentido, é preciso manter uma reflexão permanente e sistemática sobre o equilíbrio da vida e do cosmo e que essa reflexão possa favorecer uma prática consciente em relação ao compromisso de tratarmos o nosso meio ambiente com respeito como um todo (p. 76).

A sociedade contemporânea é baseada na informação, esteja ela localizada em qualquer território, o conhecimento passou a ser uma ferramenta indispensável ao universo do povo, já que a informação logo sugere a preocupação e assim torna a humanidade mais consciente e antenada com assuntos relacionados ao bem esta da sociedade e do planeta. Nessa perspectiva, é inegável a importância das contribuições e saberes dos povos indígenas, sobretudo dos anciãos que guardam muita sabedoria (BERTINHO TRUKÁ, em entrevista em 20 de abril de 2016).

Assim, a escola poderá ser, de fato, a peça fundamental para sistematizar esses saberes, transformando em conhecimentos e registrando o cotidiano do povo, para que a história permaneça viva e se perpetue de geração para geração. Em suma, o bem viver é a 
valorização da vida, da sua identidade é uma construção cultural, é a vida em plenitude, hoje sabemos alcançarmos o verdadeiro sentido do bem viver é possível (BARROS, 2018, p. 23).

Essas perspectivas são anotadas pelas professoras Pretinha Truká (Edilene Pajeú), Adriana Maria dos Santos e Fiinha Gavião (Izomar Hermina Silva-Santos), na obra recémlançada Nossas Vozes Indígenas - professoras e professores Truká: "Para nos posicionar é preciso, primeiramente, nos preparar. Acredito nos estudos como fonte básica de formação (...) mas, foi na luta diária que fui me tornando uma referência na educação indígena" (PAJEÚ, 2021, p. 72); “Ser professora indígena é romper os muros da escola, é ser indígena e pertencer à árvore genealógica do seu povo, ser atuante nos movimentos” (SANTOS, p. 2021, p. 87); "Nossa luta por uma educação diferenciada é uma constante, visto que a interferência de alguns grupos externos é muito forte"(SILVA-SANTOS, 2021, p. 101).

Não se pode negar a presença de um discurso voltado à interculturalidade no processo educativo e à descolonização dos saberes hegemônicos entre os indígenas pernambucanos, e, muito disso, se deve ao crescente processo de formação acadêmica e capacitação de professores porque passam as comunidades da RAO. Porém, ainda é imaturo certificar uma nova linha de pesquisa sendo desenvolvida na região, enquanto percebemos ensaios tão arraigados aos modelos tradicionais vigentes, como os que identificamos nos cursos de pósgraduação deste estudo.

É esse outro saber a que me propus relatar e defender como saber, porque acredito que ele exista e seja a referência para o desenvolvimento de diversas culturas, inclusiva a que costumamos intitular de brasileira. Pois, corroborando o pensamento de Silva (2014), o que seria a cultura brasileira senão a junção de tantas outras culturas, uma teia múltipla e inclassificável.

Por fim, percebe-se o intuito quase somente intuitivo dos professores indígenas, alunos de cursos de graduação e pós-graduação, pesquisadores e produtores de material de consumo escolar, na tentativa de se produzir uma ciência merecedora do respeito da academia em seu aparato tradicional. No entanto, muitos dos estudos realizados ainda esbarram em problemas comuns a qualquer produção científica no Brasil dos últimos anos, como a falta de incentivos para edificar pesquisas etnográficas de âmbito mais consistente, pesquisas humanísticas com perspectivas antropológicas. Nos trabalhos desenvolvidos pelos pesquisadores indígenas da RAO, percebe-se a predominância de estudos apenas bibliográficos e, como agravante às problemáticas encontradas nos textos, nos bancos de dados, é notória a supremacia de pesquisas sobre os povos indígenas efetivadas pelos não indígenas. Sem protagonismo nem 
respaldo dos povos pesquisados, que, por muitos anos, estiveram à margem da produção e à mercê do que lhes era designado a ser (apenas objetos de estudos), os repositórios estão repletos de trabalhos acadêmicos com mecanismos tradicionais, que, muitas vezes, nada acrescenta à realidade de exclusão do indígena brasileiro. Pelo contrário, colabora com os mecanismos de silenciamento, imposto por uma sociedade capitalista em sua essência, desde o produtor-consumidor de bens, à academia, produtora-consumidora de conceitos.

\section{Considerações Finais}

O ser humano é capaz de criar, recriar, separar, agrupar, demarcar territórios, e é dessa capacidade de enxergar (ao seu modo) o mundo que os cerca, que ele cria a "divisão" dos seres humanos em grupos sociais, o que faz surgir a discriminação, a exclusão e o preconceito, manchas indeléveis da História da Humanidade. Em países com sérios problemas sociais, como o Brasil, que até os dias atuais, convive placidamente com abissais desníveis socioeconômicos, a divisão por castas perdura e se cristaliza em uma realidade difícil de ser superada. Tais divisões são exageradamente externadas por meio dos díspares índices sociais que caracterizam os grupos étnicos brasileiros, principalmente negros e indígenas, embora a situação de pobreza atinja uma porcentagem expressiva da população.

Dialogando com Canclini (2006), percebo que as desigualdades são sentidas de diferentes maneiras pelas pessoas. Dependendo do envolvimento da própria vida com a questão, esses sentimentos podem ser mais ou menos intensos. Cada um desses grupos, que vivenciam há muitos anos tais desigualdades, tem buscado formas de enfrentá-las. No entanto, erradicar ou amenizar o abismo social no nosso meio tem se tornado a cada dia mais difícil, visto que os índices de desigualdade vêm aumentando desde 2017, segundo dados do IBGE (2018), e isso tem se tornado mais evidente nas ruas das grandes cidades, nos conflitos de terra e na desvalorização das políticas públicas que combateram essas desigualdades, notadamente nas décadas de 1990 e 2000.

É notória a luta dos povos indígenas pela reconquista de territórios. Muitos movimentos sociais em defesa dos direitos e a inserção de algumas leis a favor das questões fundiárias promoveram algumas vitórias nesse sentido e são resultados das lutas e ações que essas "minorias" têm conquistado, a despeito do interesse de elites mandatárias, da grande mídia e dos grandes proprietários de terra. Na verdade, estas conquistas são direitos 
fundamentais de uma sociedade, como a liberdade de credos, o uso de saberes tradicionais em seu sistema educacional e o respeito à diversidade cultural.

Mas, existem muitas outras formas de discriminação que agridem a dignidade humana, fazendo surgir um abismo ainda maior entre negros, brancos e indígenas, no Brasil, ainda que se apresente como país mestiço e que assuma sua etnia marcadamente afrodescendente. $\mathrm{O}$ genocídio dos povos indígenas é aqui abordado visto a necessidade de ele ser publicizado também em espaços científicos, não apenas para numerar os óbitos, mas para fazer frente ao processo de embranquecimento de nossa sociedade letrada.

A Região de Abrangência do Opará, no estado de Pernambuco tem se destacado em relação à produção de material didático indígena, de formação de professores-pesquisadores indígenas de excelência e da materialidade das línguas autóctones na construção da ressignificação sociocultural empreendida desde a retomada dos territórios indígenas da Ilha da Assunção, da Ilha de São Felix, da Serra do Arapuá, da Serra Negra e tantos outros territórios resgatados pelos seus povos originários.

Muitas têm sido as conquistas da EEI, segmento da educação que até pouco tempo atrás, nem existia. Pelo menos, para grande parte da população brasileira, em especial, para os professores e professoras da educação básica e aos próprios profissionais da EEI, que, por muitos anos, tiveram que adaptar suas práticas acadêmicas (e porque não dizer de vida?) ao sistema de ensino vigente e majoritário no Brasil.

No entanto, as conquistas dos povos indígenas andam lado a lado com as dificuldades: em muitos estados do nordeste, ainda não existe uma regulamentação para a contratação dos professores indígenas para as comunidades. ainda assim, duas sensações acalentadoras permeiam a alma de pesquisadores e indigenistas nesse momento histórico de retrocessos e desrespeito aos povos tradicionais: a primeira diz respeito à preocupação técnico-científica com os conceitos e, principalmente, com a aprendizagem; a segunda sensação relaciona-se ao contexto da Educação Escolar Indígena e Intercultural, específica e diferenciada, como deve ser, mas promovida pelo Sistema Público de Ensino em nível Nacional, de qualidade e contextualizada.

Importante citar também a prevalência de professoras indígenas, o que não só reflete uma nova porcentagem do gênero feminino nas universidades, como a participação das mulheres na construção da EEI, anunciando assim uma postura de igualdade entre homens e mulheres significativa e benéfica para o trânsito de saberes/fazeres, tão natural nas culturas 
populares, mas que a sociedade não indígena ainda não consegue o discernimento necessário para efetivar.

A guerra não está vencida, mas grandes bandeiras foram fincadas e, entre elas, de extrema importância para a ressignificação sociocultural das nações indígenas brasileiras, está a educação intercultural, aquela de fato preocupada com a verdadeira manutenção étnicocultural dos povos, atribuindo à educação, ainda que formal, o caráter de diferenciada, inclusiva e intercultural. Por isso, quando temos acesso a livros, artigos e eventos voltados à essa modalidade, produzido pelos próprios indígenas, tendemos a acreditar que esses materiais possam contribuir com/para a formação dos estudantes indígenas, pois são fruto do protagonismo indígena. Perceber as diversas inserções dos saberes tradicionais e a presença do exercício da interculturalidade é, acima de tudo, possibilitar a descolonização dos saberes, como sentido para praticar o novo, o outro, o diferente. Quando o trabalho é produzido a muitas mãos. Mãos indígenas e não indígenas conduzindo pesquisas, saberes que se interconectam e produzem o verdadeiro sentido da interculturalidade. Em diálogo com Silva (2014), compreendo que a interculturalidade acontece quando professores não indígenas não se colocam como detentores do saber absoluto, mas trazem as informações técnicometodológicas para contribuir com o fazer/saber indígena, em uma troca efetiva de saberes populares e técnicos, que se transformam em científicos, em justaposição, em solidariedade.

\section{Referências}

ATIKUM, professores e lideranças do Povo Atikum de Carnaubeira da Penha - PE. Projeto Político Pedagógico das Escolas Atikum, 2008 (2018).

AZEVEDO, Janete M. Lins de. A Educação como Política Pública. Campinas: Autores Associados, 2017.

BARDIN, Laurence. Análise de Conteúdo. Lisboa, Portugal; Edições 70, LDA, 2009.

BARROS, Maria da Penha. Entrevista, 2019. Professora Indígena Atikum, em entrevista em 04 de abril de 2019.

BAUMAN, Zygmund. Modernidade líquida. (Trad. Plínio Dentzien). 3.ed. Rio de Janeiro: Zahar, 2000.

BERTINHO TRUKÁ. Entrevista em 2019. Cacique Indígena Truká, em entrevista em 20 de abril de 2016. In: FLORÊNCIO, Roberto Remígio. Educação e Letramento Intercultural na Aldeia de Assunção do Povo Truká. Dissertação de Mestrado do Programa de Pós-Graduação 
em Educação, cultura e Territórios Semiáridos - PPGESA, Universidade do Estado da Bahia - UNEB. Juazeiro: Repositório UNEB, 2016.

BRASIL. Ministério da Educação. Constituição Federal. Brasília: Imprensa Oficial, 1988.

BRASIL. Ministério da Educação. Diretrizes para a Política Nacional de Educação Escolar Indígena. Em aberto, v. 14, n. 63, p. 175-187, 1993.

BRASIL. Referenciais para implantação de programas de formação de professores indígenas nos sistemas estaduais de ensino. Brasília: Ministério da Educação, 2001. GERLIC, S. (Ed.) Índios na visão dos índios: Comunidade Truká. Salvador: Governo do Estado da Bahia, 2003.

BRASIL, SECADI - Secretaria de Educação Continuada, Alfabetização, Diversidade e Inclusão - Ministério da Educação, 2018. Ação Saberes Indígenas na Escola - Relatório 2018. Brasília, 2019.

CANCLINI, Néstor Garcia. Hibridismo Cultural. Rio de Janeiro: Cia dos Autores, 2006. Hibridismo Cultural. São Paulo: Editores Associados, 2011.

CANCLINI, Néstor García. Culturas híbridas, poderes oblíquos: estratégias para entrar e sair da modernidade, v. 3. Rio de Janeiro: Zahar, 1997.

CANDAU, Vera M.F. e OLIVEIRA, Luiz Fernandes. Pedagogia Decolonial e Educação Antirracista e Intercultural no Brasil. Educação em revista vol. 26, n ${ }^{\circ}$ 1. Belo Horizonte, 2010.

FLORÊNCIO, Roberto Remígio. Educação e Letramento Intercultural na Aldeia de Assunção do Povo Truká. Dissertação de Mestrado do Programa de Pós-Graduação em Educação, cultura e Territórios Semiáridos - PPGESA, Universidade do Estado da Bahia UNEB. Juazeiro: Repositório UNEB, 2016.

FLORÊNCIO, Roberto Remígio (Org.). Nossas Vozes Indígenas, professoras e professores Truká. Ed. Oxente. Petrolina, 2021

IF SERTÃO PERNAMBUCANO (2014). Curso de Especialização em Educação Intercultural e Pensamento Decolonial. Projeto de curso. IFSertãoPE, 2016.

LOWIE, Robert H. The 'Tapuya'; The Cariri; The Pancararú; The Tarairiu; The Jeicó. In: STEWARD, Julian H. (Editor). Handbook of South American Indians. Washington D.C.: Smithsonian Institution \& Bureau of American Ethnology, 1946. v. 1. p. 553-567.

MACEDO, Roberto Sidnei. A etnopesquisa implicada: pertencimento, criação de saberes e afirmação. Brasília: Liber Livros, 2012.

MAINGUENEAU, Dominique. Novas tendências em Análise do Discurso. 3. Ed. Campinas: Pontes, 1997.

MAINGUENEAU, Dominique. Org. Sírio Possenti. Doze Conceitos em Análise do Discurso. São Paulo: Parábola Editorial, 2010. 
MALDONADO-TORRES, Nelson. Sobre la colonialidad del ser: contribuciones al desarrollo de un concepto. In: CASTRO-GÓMEZ, Santiago; GROSFOGUEL, Ramón (Org.). El giro decolonial. Reflexiones para una diversidad epistémica más allá del capitalismo global. Bogotá: Universidad Javeriana-Instituto Pensar, Universidad Central-IESCO, Siglo del Hombre Editores, 2007.

MIGNOLO, Walter. Histórias Globais/Projetos Locais. Colonialidade, saberes subalternos e pensamento liminar. Belo Horizonte: Editora UFMG, 2003.

MINISTÉRIO DA EDUCAÇÃO E DO DESPORTO. Lei $n^{o}$ 9.394-96, Diretrizes e Bases da Educação. Brasília: Congresso Nacional, 1996.

MINISTÉRIO DA EDUCAÇÃO E DO DESPORTO. Referencial Curricular Nacional para as Escolas Indígenas. Brasília: Secretaria de educação fundamental, 1998. RCNEI. Referencial Curricular Nacional para as Escolas Indígenas. Ministério da Educação. Brasília: MEC/SEF, 2002.

MULHERES ATIKUM. Mulheres construindo igualdade: caderno étnico-racial/ secretaria da mulher. Governo do Estado de Pernambuco. Recife: A secretaria, 2011.

OLIVEIRA, João Pacheco. Os primeiros brasileiros. Rio de Janeiro: Museu Nacional, 2014.

ORLANDI, Eni. Análise de Discurso. Princípios e procedimentos. 12. Ed. Campinas: Pontes, 2015.

PAJEÚ, Edilene Bezerra. Eu sou Pretinha Truká. In: FLORÊNCIO, R. R. (Org.). Nossas Vozes Indígenas - professoras e professores Truká. Petrolina: Ed. Oxente, 2021.

QUIJANO, Aníbal (2006). Colonialidad del poder y clasificación social. In: CASTROGÓMEZ, S.; GROSFOGUEL, R. (Org.). El giro decolonial. Reflexiones para una diversidad epistémica más allá del capitalismo global. Bogotá: Instituto Siglo del Hombre Editores, 2007.

SIMONI, Carlos Alberto Cocozza; BARANAUSKAS, Maria Cecília Calani. Pesquisa Qualitativa em Sistemas de Informação C Technical Report - IC-03-002 - Relatório Técnico. Universidade Estadual de Campinas - Unicamp Instituto de Computação - IC. February 2003.

SANTOS, Boaventura de Souza. Epistemologias do sul. Org. Maria Paulo. Coimbra: Ediçoes Almedina, 2009.

SANTOS, Boaventura Sousa e MENESES, Maria Paula (Org.). Epistemologias do sul. São Paulo: Cortez, 2010.

ANTOS, Adriana Maria. Minha história como professora indígena Truká. In: FLORÊNCIO, R. R. (Org.). Nossas Vozes Indígenas - professoras e professores Truká. Petrolina: Ed. Oxente, 2021.

SILVA-SANTOS, Izomar Hermina. Professora Fiinha Gavião. In: FLORÊNCIO, R. R. (Org.). Nossas Vozes Indígenas - professoras e professores Truká. Petrolina: Ed. Oxente, 2021. 
SILVA, Edson. Ensino e sociodiversidades indígenas: possibilidades, desafios e impasses a partir da Lei 11.645/2008. In: Práticas Pedagógicas em sala de aula. Recife: EDUFPE, 2015.

SILVA, Edson. Os povos indígenas e o ensino: reconhecendo as sociodiversidades nos currículos com a Lei 11.645. In: Ensino e pesquisa na E. B. Recife: EDUFPE, 2012.

SILVA, Luiz Fernando Vilares e. (Org.). Coletânea da legislação indigenista brasileira. Brasília: CGDTI/FUNAI, 2008.

URBAN, G. A história da cultura brasileira segundo as línguas nativas. In: CUNHA, M. C. (Org.). História dos índios no Brasil. São Paulo: Cia. das Letras, 1992.

UNIVERSIDADE DO ESTADO DA BAHIA. Opará - Núcleo de Pesquisa em Etnicidades e Movimentos Sociais. www.oparauneb.com UNEB, 2013

VEIGA-NETO, Alfredo. Educação e Pós-Modernidade: impasses e perspectivas. Rio de Janeiro: PUC, 2005.

WALSH, Catherine. Pensamiento crítico y matriz (de)colonial. Reflexiones latinoamericanas. Quito: Ediciones Abya-yala, 2005.

Como citar este artigo (Formato ABNT):

FLORÊNCIO, Roberto Remígio; ABIB, Pedro Rodolpho Jungers. Formação de Professoras/Professores e Pesquisadoras/Pesquisadores Indígenas na Região de Abrangência do Opará. Id on Line Rev. Psic., Fevereiro/2022, vol.16, n.59, p. 160-187, ISSN: 1981-1179.

Recebido: 23/01/2022;

Aceito 27/01/2022;

Publicado em: 28/02/2022. 